\title{
TF wt Allele
}

National Cancer Institute

\section{Source}

National Cancer Institute. TF wt Allele. NCI Thesaurus. Code C52270.

Human TF wild-type allele is located in the vicinity of 3q22.1 and is approximately $32 \mathrm{~kb}$ in length. This allele, which encodes serotransferrin protein, is involved in the regulation of iron transport. 